Atmos. Meas. Tech. Discuss., 4, 1233-1254, 2011

www.atmos-meas-tech-discuss.net/4/1233/2011/

\title{
An algorithm for retrieving black carbon optical parameters from thermal-optical (OC/EC) instruments
}

A novel algorithm for retrieving aerosol

A. Andersson et al.

A. Andersson ${ }^{1}$, R. J. Sheesley ${ }^{1,2}$, E. N. Kirillova ${ }^{1}$, and Ö. Gustafsson ${ }^{1}$

${ }^{1}$ Department of Applied Environmental Science (ITM) and Bert Bolin Centre for Climate Research, Stockholm University, Sweden

${ }^{2}$ Department of Environmental Science, Baylor University, Waco, TX, USA

Received: 4 February 2011 - Accepted: 21 February 2011 - Published: 24 February 2011

Correspondence to: A. Andersson (august.andersson@itm.su.se)

Published by Copernicus Publications on behalf of the European Geosciences Union.

\section{Title Page}

\section{Abstract}

Introduction

Conclusions

References

Tables

Figures

14

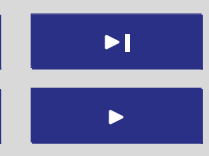

Back

Close

\section{Full Screen / Esc}

Printer-friendly Version

Interactive Discussion 


\section{Abstract}

Through absorption of sun light atmospheric black carbon (BC) is expected to influence regional/global climate by warming the atmosphere and dimming the surface. To evaluate the impact of these effects it is of interest to examine both the radiative properties 5 of $\mathrm{BC}$ and the concentrations in air. Building on recent developments we present a novel application for combining these two aspects using the common thermal-optical (OC/EC) instrument. By correlating the OC/EC laser transmission with the FID-carbon detection non-carbon contributions to the light attenuation are detected. Such analysis allows the calculation of mass absorption cross-sections (MACs) for BC, corrected for certain in-organic components. This approach has been applied to data from two $S$ Asian and two $N$ European sites, including a time series analysis for one of the $N$ European sites. Taken together this study demonstrates broad applicability for this method while providing new insights into the optical properties of BC.

\section{Introduction}

15 The interaction of aerosols with sunlight is one of the major uncertainties in our current understanding of Earth's climate (Forster et al., 2007; Ramanathan et al., 2001a). Black carbon (BC) aerosols are particularly pertinent as these strongly absorb sunlight and thereby heat the atmosphere and dim the surface (Jacobson, 2001; Ramanathan and Carmichael, 2008). The effects of $\mathrm{BC}$ on overall anthropogenic radiative forcing is believed to be considerable in regions such as south and east Asia, as well as for the Arctic (Ramanathan et al., 2001b; Menon et al., 2002; McConnell et al., 2007). Quantification of the light-interacting properties of $\mathrm{BC}$ aerosols is therefore of key importance in order to estimate the overall radiative forcing and proposing effective aerosol emission control strategies.

$25 \quad \mathrm{BC}$ is formed during the incomplete combustion of biomass and fossil fuels. BC is not a distinct chemical species, but rather defines a range of states from a few
4, 1233-1254, 2011

\section{A novel algorithm for retrieving aerosol}

A. Andersson et al.

\section{Title Page}

Abstract Introduction

Conclusions

References

Tables

Figures

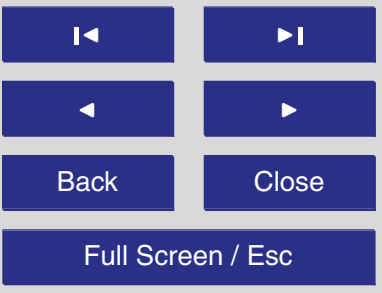

Printer-friendly Version

Interactive Discussion 
aromatic rings to graphite. The lack of a strict definition and the different focus in different fields has lead to several partially overlapping terms that together describe the "BC continuum" (Hedges et al., 2000; Hammes et al., 2007), The term light-absorbing carbon (LAC) has been proposed for BC which is strongly light absorbing, as opposed 5 to "brown carbon" (Andreae and Gelenscer, 2006; Bond and Bergstrom, 2006).

The thermo-optical (TO) method is the most commonly used approach in the atmospheric sciences for distinguishing and quantifying the aerosol mass of organic carbon (OC) and elemental carbon (EC) (e.g., Schauer et al., 1999; McDonald et al., 2000; He et al., 2001). The obtained mass amount of EC is often used to establish transfer 10 functions, called mass absorption cross section (MAC, see Materials and Methods for a further discussion of this term), for converting optical data (e.g., particle soot absorption photometer (PSAP) or aethalometers) into BC mass concentrations. In the original TO method setup the two carbon forms OC and EC were separated by combustion in anoxic $(\mathrm{OC})$ and a partially oxic atmospheric environment (EC). A major challenge with 15 this setup is that $\mathrm{OC}$ often pyrolizes during the anoxic phase, and therefore inadvertently creates "EC" during the experiment. Laser transmission/reflection is nowadays therefore monitored through the filter to circumvent inconsistencies regarding the split between OC and EC in TO Transmission (TOT) or TO Reflection (TOR) approaches (e.g., Chow et al., 2003). The split between OC and EC is then defined as the point in the TOT stepped carrier gas composition-temperature program where the transmission returns to the initial value.

The laser transmission of the widely used Sunset thermal-optical instrument was recently utilized by Ram and Sarin (2009) (Ram et al., 2010), in combination with concurrent aerosol carbon quantification to derive light extinction properties of the filtercollected aerosol BC. This methodology has several advantages: (i) it does not require any additional instrumentation to estimate the light extinction, (ii) light extinction, $\mathrm{OC}$ and EC are derived simultaneously on exactly the same sample and (iii) since the oven burns off all sample, a natural base-line for each filter is achieved. This setup is similar to other filter-based techniques for measuring light absorption, such

\section{A novel algorithm for retrieving aerosol}

A. Andersson et al.

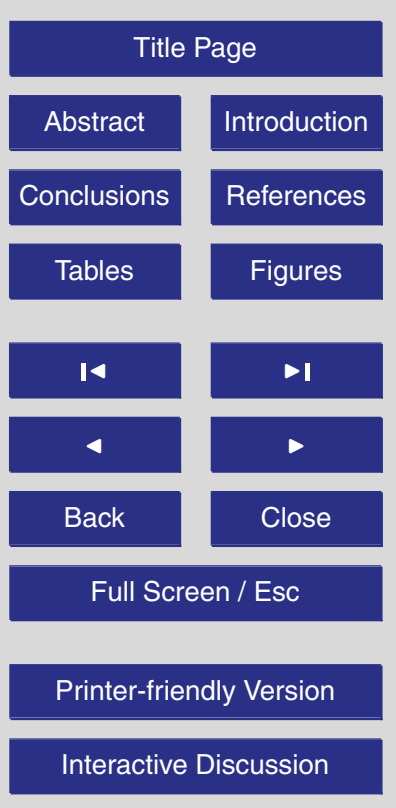


as the aethalometer and the particle soot absorption photometer (PSAP, Lin et al., 1973; Hansen et al., 1984; Bond et al., 1999; Gelenscer, 2004). These methodologies are routinely used at various sampling sites around the world, including the Polar Regions, city locations, mountain sites and forests (e.g., Bodhaine, 1995; Schmid et 5 al., 2006; Bergstrom et al., 2007). These methods utilize single or multiple wavelength light extinction to indirectly approximate the $\mathrm{BC}$ abundance. The coupling between light extinction and $\mathrm{BC}$ concentrations are made through calibrations, often involving Sunset Instruments TOT-defined EC as an analogue for BC. The "calibration" constant used is the MAC, by which the light attenuation measured by the aethalometer or the PSAP is converted into BC concentrations.

One major disadvantage with techniques such as the aethalometer and the PSAP is that the connection between the amounts of light absorbing carbon and light extinction is not always clear, as other compounds may cause light extinction (Seinfeld and Pandis, 2006). Here a novel algorithm for analyzing the thermo-optical laser transmission 15 is presented. This algorithm combines the FID signal (flame ionization detector) with the optical signal to distinguish between high temperature non-carbon optical extinction and optical extinction that is correlated with the carbon signal. This algorithm is demonstrated using samples from two regional background sites in south Asian background sites, Hanimaadhoo Island, the northern most islands in the republic of Maldives and Sinhagad in Western India, and two samples from rural (Aspvreten) and urban (Stockholm) sites in $N$. Europe (Sweden). Finally, this methodology was used to calculate the mass absorption cross-section (MAC) and the light attenuation coefficient (ATN) for these samples.

\section{AMTD}

$4,1233-1254,2011$

\section{A novel algorithm for retrieving aerosol}

A. Andersson et al.

\section{Title Page}

Abstract Introduction

Conclusions

References

Tables

\section{Figures}

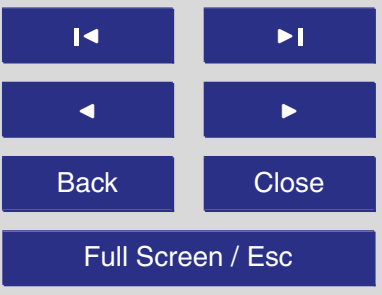

Printer-friendly Version

Interactive Discussion 


\section{Materials and methods}

\subsection{Lambert-Beer Law and definitions}

According to the Lambert-Beer Law, light intensity attenuation $\left(/ / I_{0}\right)$ is proportional to the negative exponential of the path length $(d)$, concentration $(C)$ and the extinction 5 coefficient, here referred to as the mass absorption cross section (MAC):

$\frac{I}{I_{0}}=e^{-\mathrm{MAC} \cdot d \cdot \mathrm{C}}$

Strictly, this Equation is only valid for an infinitely diluted medium with well-defined optical properties. However, it is still useful for wider set of applications, as it facilitates comparisons of, e.g., concentrations and optical properties. In atmospheric sciences, there is currently a lack of consistency in the terminology regarding the different coefficients used in relation to the Lambert-Beer Law (Bond and Bergstrom, 2006). Here, the concentration will refer to the mass of atmospheric particles per volume units $\left(\mathrm{g} \mathrm{m}^{-3}\right)$. Since Eq. (1) in the present setting is applied to filter sampling, the path length is given by the total air volume sampled $(V)$ divided by the filter area $(A, d=V / A)$. Con15 sequently, the MAC has the units of $\mathrm{m}^{2} \mathrm{~g}^{-1}$. In the literature there is diversity in the definitions, and the MAC is sometimes also referred to the mass absorption efficiency (MAE). Since light is attenuated not only by aerosol absorption, but also scattering the terminology MAC or MAE is somewhat misleading. However, we have chosen to use the MAC terminology in this contribution, as it is accepted in the literature (Bond and Bergstrom, 2006). The MAC is a measure of light attenuation normalized to the mass loadings per filter area.

Since the MAC is dependent on a correct estimate of the mass of the scattering/absorbing aerosols it is useful to define the light attenuation constant, (ATN, which is the sum of the scattering and absorption light attenuation) which normalizes the light

\section{A novel algorithm for retrieving aerosol}
A. Andersson et al.

Title Page

Abstract

Introduction

Conclusions

References

Tables

Figures

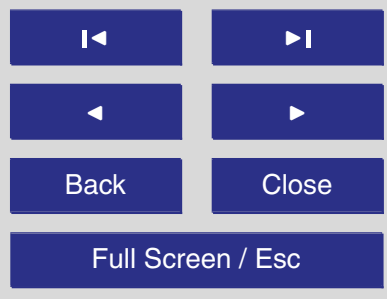

Printer-friendly Version

Interactive Discussion 
reduction caused by aerosols by sampled air volume and filter area:

$\operatorname{ATN}=\frac{-\ln \left|\frac{1}{T_{0}}\right|}{d}=\frac{-A \cdot \ln \left|\frac{1}{T_{0}}\right|}{V}=\operatorname{MAC} \cdot \mathrm{C}$

The light attenuation has the unit $\mathrm{m}^{-1}$, and is an estimate of the decrease of light transmission due to the presence of aerosols per meter ambient air. By assuming a 5 well-mixed boundary layer, calculating the product of the light extinction coefficient and the height of the boundary layer gives an estimate of the direct aerosol dimming effect.

\subsection{Thermal-optical analysis and laser transmission algorithm}

The aerosol bulk organic carbon (OC) and elemental carbon (EC) contents were analyzed with Sunset thermal-optical transmission carbon analyzer (Sunset Laboratory,

10 Tigard, OR, USA, Birch and Cary, 1996). The temperature program used was the National Institute of Occupational Safety and Health (NIOSH, 1999). The carbon mass content (measured through a flame ionization detector, FID) and the light transmission through the filter are simultaneously quantified. The amount of EC is defined as the carbon mass that is collected once the laser transmission returns to the initial value 15 (e.g., Birch and Cary, 1996).

In the recent method developed by Ram and Sarin (2009) the $(\lambda=768 \mathrm{~nm})$ OCEC laser transmission is used to calculate optical properties of the sample according to:

$\frac{I}{I_{0}}=\frac{T_{\text {start }}}{T_{\text {end }}}$

where $T_{\text {start }}$ is the initial value of the transmission and $T_{\text {end }}$ is the final value of the 20 transmission. Combined with Eqs. (1) and (2) this value was then used to calculate the light attenuation (ATN) and the mass absorption cross-section (MAC). However, it has been found that the laser transmission in the OCEC experiment can continue to increase even after the carbon signal has leveled off, Fig. 1. It is clear that this increase

\section{A novel algorithm for retrieving aerosol}

A. Andersson et al.

Title Page

Abstract

Introduction

Conclusions

References

Tables

Figures

14

14

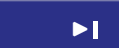

4

Back

$>$

Back

Close

Full Screen / Esc

Printer-friendly Version

Interactive Discussion

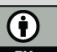


in transmission must be due to some component(s) that do(es) not contain carbon, i.e., inorganic compounds. For such samples, utilizing the methodology outlined in Eq. (3) would overestimate the light extinction attributed to carbonaceous materials, such as $\mathrm{BC}$ and LAC.

5 There is thus a need to develop a robust methodology that is based on a cut-off point where the transmission is no longer influenced by LAC. A straight-forward methodology would be to define a cut-off based on a change in the carbon signal (the "derivative"). The drawback of such a strategy is that the relation between the transmission and the carbon signal is often highly non-linear, Fig. 1. Thus, by arbitrarily defining a cut-off, 10 this may lead to a low consistency among highly variable samples.

Another strategy would be to focus on the laser transmission signal, and search for an inflection point, at which a novel contribution to the transmission could be expected. Such point could be calculated by looking for a minimum in the point by point difference (the "derivative") of the transmission signal. This strategy is problematic since certain 15 samples might not have a well-defined inflection point, and the existence of such might be uncorrelated with the decaying carbon signal. To overcome this problem a combined strategy is therefore proposed. By computing the point by point change of the transmission signal and dividing it by the point by point change in the carbon signal a "response function" is obtained. This response function is sensitive to changes in both light transmission and carbon amounts. At the point where carbon is decreasing, while the laser is increasing, the sensitivity function will have a local maximum. To calculate this point a Matlab routine was developed using Matlab version 7.9.0 (The MathWorks, Natick, USA).

One problem with defining this local maximum of the response function is that there 25 might be many such maxima during a run, especially if the signals are noisy, Fig. $1 \mathrm{~b}$. For the currently analyzed samples, the noise was reduced by calculating the running average of the transmission signal (the carbon signal was more stable), with an average of 30 data points. For the current applications the full OC/EC run was recorded using 810 data points. To further restrict the possibility for "false positives", the interval in

\section{A novel algorithm for retrieving aerosol}
A. Andersson et al.

\section{Title Page}

Abstract Introduction

Conclusions References

Tables Figures

14

14

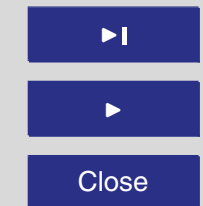

Back

Close

Full Screen / Esc

Printer-friendly Version

Interactive Discussion 
which the maximum of the response function is examined by manual inspection. Of key importance for the response function to be informative is that the laser transmission signal and the carbon signal are synchronized. Since it takes time for the burned off material to be transported to the FID (a few seconds), this "transit time" needs to 5 be subtracted from the timing of the carbon signal before calculating the response function.

This strategy makes it possible to calculate the level at which the laser transmission stops being influenced by carbon containing materials $\left(T_{\mathrm{EC}}\right)$. This point can then be used to calculate the light transmission related specifically and only to the EC compo10 nent $\left(I_{\mathrm{EC}} / I_{0}\right)$ :

$\frac{I_{\mathrm{EC}}}{I_{0}}=\frac{T_{\text {start }}+T_{\text {end }}-T_{\mathrm{EC}}}{T_{\text {end }}}$

In Sect. 3, both Eqs. (3) and (4) are used to calculate the mass absorption cross section and the light attenuation in order to evaluate the effect on derived aerosol optical parameters on inadvertent inclusion of the non-carbonaceous contributions.

\subsection{Aerosol sampling and TOT-OCEC measurements}

Samples of ambient air were collected at four different sites to test and demonstrate the algorithm. Samples were used from the Maldives Climate Observatory on Hanimaadhoo Island ( $\left.\mathrm{MCOH}, 6^{\circ} 46^{\prime} 34^{\prime \prime} \mathrm{N}, 73^{\circ} 10^{\prime} 60^{\prime \prime} \mathrm{E}\right)$, the northernmost Island in the Republic of Maldives (test samples of 10-16 April 2008). The method was also tested with samples from another South Asian site, the mountain top site (1400 ma.s.I.) operated by the Indian Institute of Tropical Meteorology at Sinhagad (SIN, $18^{\circ} 21^{\prime} 59^{\prime \prime} \mathrm{N}$, $73^{\circ} 45^{\prime} 21^{\prime \prime} \mathrm{E}$ ) in Western India (samples from 4-10 March 2009). The method was additionally tested on Northern European aerosols obtained from the European Monitoring and Evaluation Programme (EMEP) station in Aspvreten (ASP, $58^{\circ} 48^{\prime} 21^{\prime \prime} \mathrm{N}$, $251^{\circ} 24^{\prime} 18^{\prime \prime} \mathrm{E}$ ), Sweden (samples from 6-12 October 2008). Finally, temporal variability in the derived $\mathrm{BC}$ optical parameters were investigated using 2-3 days interval time

\section{AMTD}

$4,1233-1254,2011$

\section{A novel algorithm for retrieving aerosol}

A. Andersson et al.

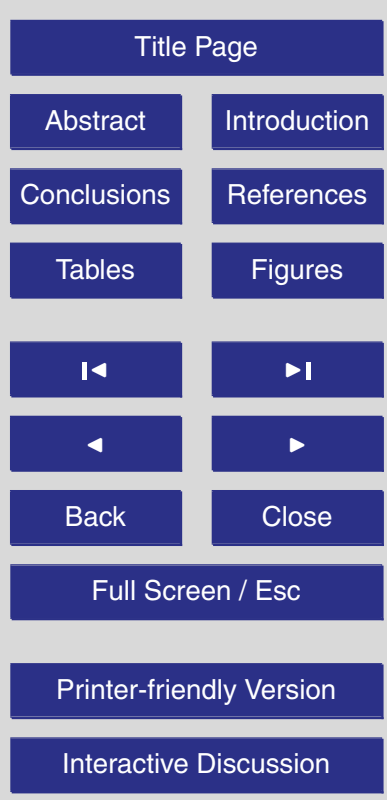


series ( 3 days for weekends) collected from a $15 \mathrm{~m}$ platform on the top floor of the Geoscience building at Stockholm University campus (STO, $59^{\circ} 21^{\prime} 58^{\prime \prime} \mathrm{N}, 18^{\circ} 03^{\prime} 29^{\prime \prime} \mathrm{E}$ ), Stockholm, Sweden, 19 August-5 October 2009. The site is located in a mixed grassland-forested area, a "City National park", about $120 \mathrm{~m}$ away from a highway.

5 To include all aerosol carbon fractions, high-volume total suspended particle (TSP) air samples were obtained as detailed earlier (e.g., Zencak et al., 2007; Gustafsson et al., 2009). The ambient aerosols were collected onto low volume $\left(0.5-0.7 \mathrm{~m}^{3} \mathrm{~h}^{-1}\right) 47 \mathrm{~mm}$ (MCOH, SIN and ASP) or high volume (14-19 $\left.\mathrm{m}^{3} \mathrm{~h}^{-1}\right) 142 \mathrm{~mm}$ (STO) quartz fiber filters (QFF; Millipore, Billerica, MA), pre-combusted at $450^{\circ} \mathrm{C}$ for $5 \mathrm{~h}$. Field blanks were 10 obtained by placing and removing the blank filters in the filter holder at site. In order to estimate the errors and error propagation, triplicates were measured at least once for all sites.

\subsection{Filter sampling and optical measurements}

Filter-based measurements of the optical properties of the deposit are associated with 15 some technical and principal challenges. A major issue with optical measurements is the presence of multiple scattering caused by the filter media (e.g., Bond et al., 1999). These scattering effects may be difficult to account for by theoretical means, and since no two filters are exactly the same variations are expected to occur. For aerosol samples, it has been found that these effects also are influenced by aerosol 20 parameters such as the mixing state (Bond and Bergstrom 2006, Weingarter et al., 2003). To correct for these effects, empirical correction factors $(C)$ have been developed for calculating the mass and light extinction factors (Bond et al., 1999, Weingarter et al., 2003).

Besides multiple scattering effects, shadowing effects also may influence the light 25 transmission. This shadowing effect occur at high filter loadings, where the laser transmission is strongly attenuated by the higher lying layers on the filter, and thus do not represent the entire sample, thus displaying non-Lambert-Beer behavior. These effects can partially be controlled by ensuring that the sampling time/air flow rates match
AMTD

$4,1233-1254,2011$

\section{A novel algorithm for retrieving aerosol}

A. Andersson et al.

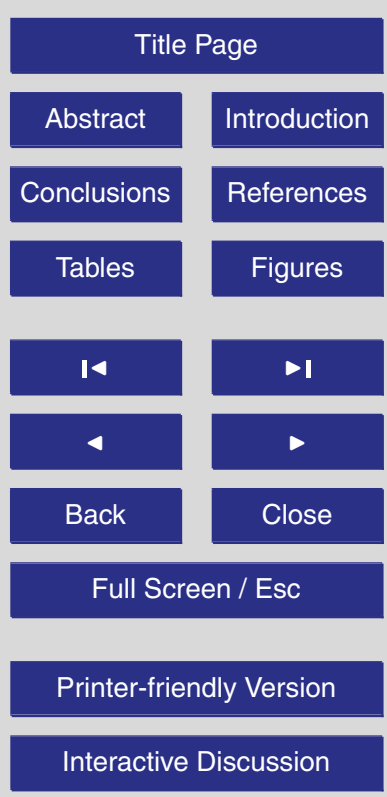


the ambient loadings. Besides differences in filter loadings, variations have also been observed when comparing freshly emitted and aged soot LAC particles. The shadowing effect for well-mixed aerosols is "almost negligible" as compared with fresh soot particles (Weingartner et al., 2003). In the current study, the calculated mass and light 5 extinction coefficients were divided by the correcting factor $C=3.6 \pm 0.6$, since such values could be expected for internally mixed aerosols. No correction for the shadowing effect was introduced, since the sampled aerosols were expected to be well-mixed.

\section{Results and discussion}

\subsection{Comparison of the two strategies for deriving BC optical properties from the thermal-optical instrument}

By comparing the light attenuation coefficients calculated using Eq. (3) (ATN $\mathrm{EC}_{\mathrm{EC}}$ ) with

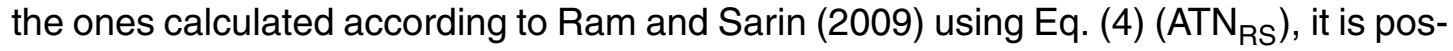
sible to estimate the influence of high temperature non-carbon carbon contributions to the light attenuation. The ratios of $\mathrm{ATN}_{\mathrm{EC}} / \mathrm{ATN}_{\mathrm{RS}}$ (Fig. 2a and Table 1) are consistently (1) all sites, demonstrating that the inclusion of the late-program increase in transmission, not related to carbon-containing aerosols, leads to an overestimate of "ATN" for $\mathrm{BC}$ aerosols. The results show that inter-site variations of the $A T N_{E C} / A T N_{R S}$ - ratio are larger than the temporal variations at the Stockholm site.

\subsection{Inter-site comparisons}

20 In Fig. 2b-c the variations in ATN and MAC are plotted as a function of the four different sites: Aspvreten, Sinhagad, Hanimaadhoo and Stockholm. The values of the light extinction vary by at least a factor of three $\left(1.7-7.0 \mu^{-1}\right)$, Fig. $2 b$. The two south Asian sites were probed during the high aerosol loading winter season. However, the two sites are relatively remote background sites. The highest value is observed at SIN in
AMTD

$4,1233-1254,2011$

\section{A novel algorithm for retrieving aerosol}

A. Andersson et al.

\section{Title Page}

Abstract Introduction

Conclusions

References

Tables

Figures

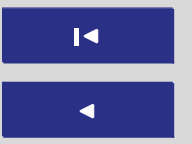

$>1$

Back $\checkmark$

Full Screen / Esc

Printer-friendly Version

Interactive Discussion 
India $\left(7.0 \mu \mathrm{m}^{-1}\right)$, whereas the three other sites have similar values $\left(1.7-2.6 \mu \mathrm{m}^{-1}\right)$. The mass absorption cross-section (MAC) provides a link between optical measurements such as PSAP and aethalometers and BC concentrations. Comparing with the trends observed for the light attenuation coefficients, the trends for MACs are shifted Fig. 2c 5 and Table 1. The MACs of SIN and ASP (17.4 and $13.9 \mathrm{~m}^{2} \mathrm{~g}^{-1}$, respectively) are more than twice the values for STO and $\mathrm{MCOH}$ (5.5 and $6.6 \mathrm{~m}^{2} \mathrm{~g}^{-1}$, respectively). In these plots, the error bars were calculated from triplicate samples, and it is thus clear that the differences exceed the measurement variance. It is not possible to draw any general conclusions for inter-site variations from this limited data set. However, these data shows that large regional variations are observed, emphasizing the importance of investigating site variations of the MACs.

\subsection{Stockholm time-series}

In order to explore the temporal variations in light extinction properties at a single site a six week sampling campaign was executed in Stockholm, Fig. 3. OC and EC concentrations in air as well as the light attenuation constant follow similar temporal patterns for the first part of the sampling period. The general trend is that weekends (marked by stars) have lower values than the rest of the week for all three parameters. After the 18 October this trend is no longer present. This change is accompanied with a shift in mean wind direction, changing from $203 \pm 22^{\circ}$ to $248 \pm 20^{\circ}$, and thus to more westerly winds, as calculated using data from the Swedish Meteorology and Hydrology Institute (SMHI) MESAN meso-scale analysis system. These changes in wind direction do not in themselves explain the change in the temporal pattern, but indicate a shift in the local meteorological setting. The lower values observed for the weekends are likely to be attributed to lesser weekend traffic on the nearby E18 motorway. The E18 is heavily trafficked during weekdays as it is one of the major routes for car commuters to and from the centre of Stockholm.

\section{A novel algorithm for retrieving aerosol}

A. Andersson et al.

\section{Title Page}

Abstract Introduction

Conclusions

References

Tables

Figures

I

14

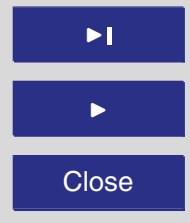

Back 
It is interesting to note that the light attenuation constant follows a similar trend as the EC levels, Fig. 3a-b. However, it is important to examine how large these variations are compared with the measurement errors. The ratio between the standard deviations of the temporal variations and variations in triplicate analyses are in the order of 10 for

5 EC concentrations and around 2 for the light attenuation constant. Thus, the variations in EC are well above the "signal to noise", but for the light attenuation constant it is important not to overemphasize these trends. The MAC is obtained by calculating the ratio of the light extinction coefficient and EC. It is clear that the weekend effects observed for the light attenuation and the EC cancel out when calculating the MAC,

10 Fig. 3c. This indicates that the mass extinction cross-section for this region is relatively constant over time, implying similar optical properties thus combustion sources over time.

\subsection{Comparisons with other filter based methods}

Filter-based measurements of light attenuation and estimates have been developed 15 over a few decades. Several different techniques are currently used in field studies, including aethalometers, PSAPs and soot photometers (Lin et al., 1973; Hansen et al., 1984; Gelenscer, 2004). These methods all share similar technical problems, including sampling artifacts such as adsorption/desorption of compounds from the filter and chemical reactions, but also more principal problems such as multiple scattering 20 and shadowing effects (e.g., Bond et al., 1999; Gelenscer, 2004; Bond and Bergstrom, 2006). As was discussed in the Materials and Methods section, semi-empirical ways to account for the latter two effects has been applied to the present data. These corrections are important to keep in mind when comparing with other estimates of the light attenuation parameters.

25 Another important factor to consider is the wavelength dependence of the optical properties. The present data were recorded at $768 \mathrm{~nm}$, whereas, e.g., PSAP data routinely are recorded at $\sim 550 \mathrm{~nm}$. The $768 \mathrm{~nm}$ is less likely to be interfered by the light absorption of "brown carbon" compounds, but may be more influenced by the
AMTD

4, 1233-1254, 2011

\section{A novel algorithm for retrieving aerosol}

A. Andersson et al.

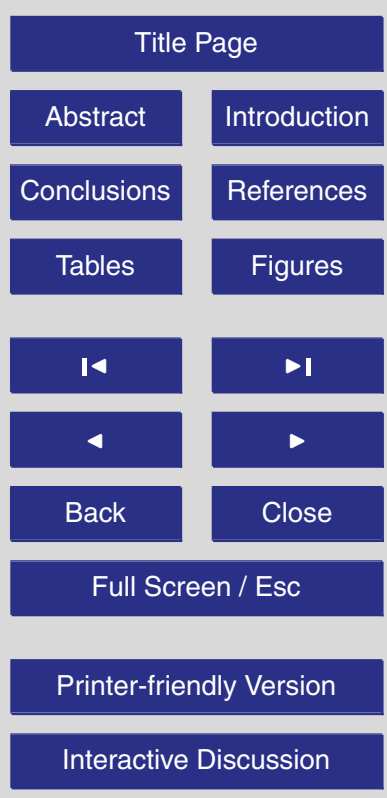


scattering of inorganic species. Aethalometer data are sometimes recorded using several different wavelengths, in order to calculate e.g. the Angström coefficient, but is also many times recorded using a single wavelength apparatus. Comparisons of field campaigns from different regions show that the wavelength dependence of the aerosol 5 optical depth is highly variable (Bergstrom et al., 2007). These trends however do not only reflect $\mathrm{BC}$ or $\mathrm{LAC}$, but all aerosol components. The wavelength dependence for "pure" BC absorption is expected to depend on the size of the graphitic clusters (Bond, 2001).

Besides instrumental and technical issues of filter-based measurements of aerosol 10 optical parameters it is also important to examine sample variations. Such variations may be due to several different factors, including chemical composition, internal/external mixing, size distribution and shape (Bond and Bergstrom, 2006). It is therefore of interest to examine these parameters at various different sites and time points, including different distances from sources. There is a broad set of literature values of 15 the light extinction coefficients (e.g., Bergstrom and Bond, 2006; Snyder and Schauer, 2007). Based on a collection of 17 different studies Bergstrom and Bond proposed a universal value of the $B C$ mass extinction coefficient $\left(M_{A C}\right)=7.5 \pm 1.2 \mathrm{~m}^{2} \mathrm{~g}^{-1}$ was proposed. This value represents freshly made $B C$ particles measured at $550 \mathrm{~nm}$. However, large variations have been reported for different conditions. For instance, it has been shown that the values of $\mathrm{MAC}_{\mathrm{BC}}$ vary linearly with the EC/PM2.5 (PM2.5 - particulate matter with a radius less than $2.5 \mu \mathrm{m}$ ) ratio for burning of biomass materials (Habib et al., 2008). The $\mathrm{MAC}_{\mathrm{BC}}$ values calculated by the simultaneously obtained optical and BC mass data with the TOT-OC/EC instrument approach by Ram and Sarin (2009) range between $3.4-16.9 \mathrm{~m}^{2} \mathrm{~g}^{-1}$, for different sites in India.

25 The present values range between $3.5-18.2 \mathrm{~m}^{2} \mathrm{~g}^{-1}$ when not accounting for the non-carbon contributions $\left(\mathrm{MAC}_{\mathrm{RS}}\right)$. The non-carbon contribution of these values, as determined by the present method, ranges $\sim 5-50 \%$ of the $\mathrm{MAC}_{\mathrm{RS}}$, depending on site, Table 1. Ram and Sarin (2009) used a multiple scattering correction of 2.14 , but in the current contribution we used 3.6, as we assume the samples to be well-mixed.
AMTD

4, 1233-1254, 2011

\section{A novel algorithm for retrieving aerosol}

A. Andersson et al.

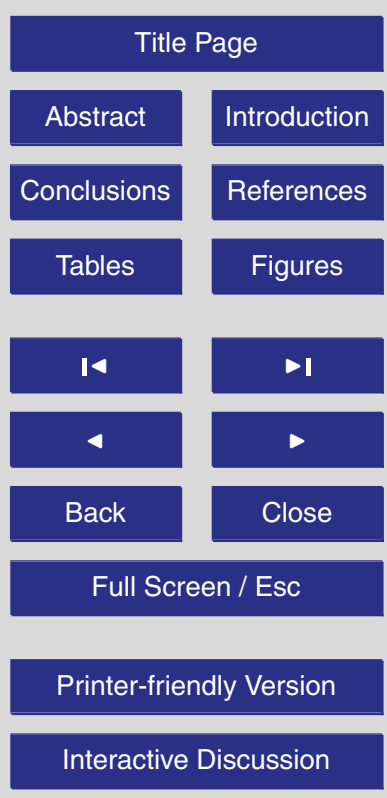


The only site in the current study which is expected to lie relatively close to source regions is the Stockholm site. Since the Stockholm values are in general lower than other ones, one might argue that the $\varepsilon$ is underestimated at this site. The average Stockholm values are $M_{\mathrm{RAC}}=6.5 \mathrm{~m}^{2} \mathrm{~g}^{-1}$ and $M A C_{\mathrm{EC}}=5.0 \mathrm{~m}^{2} \mathrm{~g}^{-1}$, Table 1 . However, by using 5 a scattering correction of 2.14 instead of 3.6 one obtains $M_{A C} C_{R S}=10.9 \mathrm{~m}^{2} \mathrm{~g}^{-1}$ and $M A C_{E C}=8.4 \mathrm{~m}^{2} \mathrm{~g}^{-1}$. The latter value lies within the range of $7.5 \pm 1.2 \mathrm{~m}^{2} \mathrm{~g}^{-1}$ proposed by Bond and Bergstrom for freshly emitted LAC. However, it is important to note that present results were obtained at a different wavelength.

\section{Conclusions}

10 A novel algorithm for extracting optical properties of BC/LAC from the common opticalthermal $(\mathrm{OC} / \mathrm{EC})$ technique is presented. This algorithm combines the laser transmission signal with the FID signal of the OC/EC instrument to distinguish between carbon and non-carbon components of the light extinction. This allows computation of mass absorption cross-sections (MACs) for the investigated samples, corrected for high tem15 perature non-carbon contributions. The simultaneous measurements of optical optical properties and the carbon mass on the same filter, as well as the natural baseline obtained at the end of the OC/EC temperature program offers additional advantages of this approach.

The current methodology was successfully applied to data from Indian and Maldivian background sites as well as rural and urban sites in $N$. Europe, including a six week time series at site in metropolitan Stockholm. Taken together, this shows that the current development have a wide applicability and provide novel insights into the characterization of the optical properties of BC/LAC.
AMTD

$4,1233-1254,2011$

\section{A novel algorithm for retrieving aerosol}

A. Andersson et al.

\section{Title Page}

Abstract Introduction

Conclusions

References

Tables

Figures

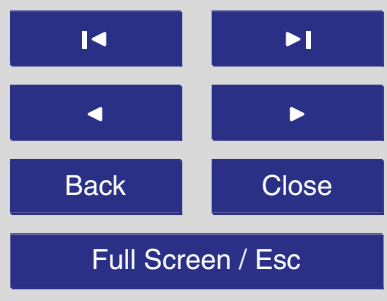

Printer-friendly Version

Interactive Discussion 
Acknowledgements. We acknowledge financial support from the Swedish Research Council for Environment, Agricultural Sciences and Spatial Planning (FORMAS Contract no. 214-2009970). ÖG also acknowledges financial support as an Academy Researcher from the Swedish Royal Academy of Sciences and AA acknowledges financial support from the Knut and Alice 5 Wallenberg Foundation. We also acknowledge SMHI for providing MESAN data for Stockholm.

\section{References}

Andreae, M. O. and Gelencsér, A.: Black carbon or brown carbon? The nature of lightabsorbing carbonaceous aerosols, Atmos. Chem. Phys., 6, 3131-3148, doi:10.5194/acp6-3131-2006, 2006.

10 Bergstrom, R. W., Pilewskie, P., Russell, P. B., Redemann, J., Bond, T. C., Quinn, P. K., and Sierau, B.: Spectral absorption properties of atmospheric aerosols, Atmos. Chem. Phys., 7, 5937-5943, doi:10.5194/acp-7-5937-2007, 2007.

Birch, M. E. and Cary, R. A.: Elemental carbon-based method for occupational monitoring of particulate diesel exhaust: methodology and exposure issues, Analyst, 121, 1183-1190, 1996.

Bodhaine, B. A.: Aerosol absorption-measurements at Barrow, Mauna-Loa and the South-Pole, J. Geophys. Res., 100, 8967-8975, 1995.

Bond, T., Anderson, T. L., and Campbell, D.: Calibration and inter-comparison of filter-based measurements of visible light absorption by aerosols, Aerosol. Sci. Technol., 30, 582-600, 1999.

Bond, T.: Spectral dependence of visible light absorption by carbonaceous particles emitted from coal combustion, Geophys. Res. Lett., 28, 4075-4078, 2001.

Bond, T. C. and Bergstrom, R. W.: Light absorption by carbonaceous particles: an investigative review, Aerosol Sci. Tech., 40, 27-67, 2006.

25 Chow, J. C., Watson, J. G., Pritchett, L. C., Pierson, W. R., Frazier, C. A., and Purcell, R. G.: The DRI thermal/optical reflectance carbon analysis system: description, evaluation and applications in US air quality studies, Atmos. Environ., 27A, 1185-1201, 1993.

Gustafsson, Ö., Kruså, M., Zencak, A., Sheesley, R. J., Granat, L., Engström, E., Praveen, P. S., Rao, P. S. P., Leck, C., and Rodhe, H.: Brown clouds of south Asia: Biomass of fossil fuel combustion?, Science, 323, 495-498, 2009.

\section{AMTD}

4, 1233-1254, 2011

\section{A novel algorithm for retrieving aerosol}

A. Andersson et al.

\section{Title Page}

Abstract Introduction

Conclusions References

Tables

Figures

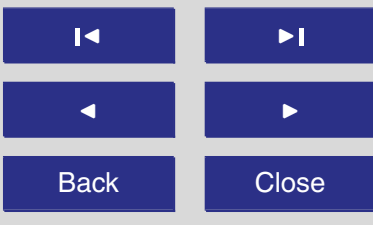

Full Screen / Esc

Printer-friendly Version

Interactive Discussion 
Habib, G., Venkataraman, C., Bond, T. C., and Schauer, J. J.: Chemical, microphysical and optical properties of primary particles from the combustion of biomass fuels, Environ. Sci. Technol., 42, 8829-8834, 2008.

Hammes, K., Schmidt, M. W. I, Smernik, R. J., Currie, L. A., Ball, W., PNguyen, T. H., Lou5 chouarn, P., Houel, S., Gustafsson, Ö., Elmquist, M., Cornelissen, G., Skjemstad, J. O., Masiello, C. A., Song, J., Peng, P., Mitra, S., Dunn, J. C., Hatcher, P. G., Hockaday, W. C., Smith, D. M., Hartkopf-Froeder, C., Boehmer, A., Lueer, B., Huebert, B. J., Amelung, W., Brodowski, S., Huang, L., Zhang, W., Gschwend, P. M., Flores-Cervantes, D. X., Largeau, C., Rouzaud, J.-N., Rumpel, C., Guggenberger, G., Kaiser, K., Rodionov, A., Gonzalez-Vila, F. J., Gonzalez-Perez, J. A., de la Rosa, J. M., Manning, D. A. C., Lopez-Capel, E., and Ding, L.: Comparison of quantification methods to measure fire-derived (black/elemental) carbon in soils and sediments using reference materials from soil, water and the atmosphere, Global Biogeochem. Cy., 21, GB3016, doi:10.1029/2006GB002914, 2007.

Hedges, J.I., Eglinton, G., Hatcher, P.G., Kirchman, D.L., Arnosti, C., Derenne, S., Ever15 shed, R.P., Kögel-Knabner, I., de Leeuw, J.W., Littke, R., Michaelis, W., Rullkötter, J.: The molecularly-uncharacterized component of nonliving organic matter in natural environments, Organ. Geochem., 31, 945-958, 2000.

Lelieveld, J., Crutzen, P. J., Ramanathan, V., Andreae, M. O., Brenninkmeijer, C. A. M., Campos, T., Cass, G. R., Dickerson, R. R., Fischer, H., de Gouw, J. A., Hansel, A., Jefferson, A., Kley, D., de Laat, A. T. J., Lal, S., Lawrence, M. G., Lobert, J. M., Mayol-Bracero, O. L., Mitra, A. P., Novakov, T., Oltmans, S. J., Prather, K. A., Reiner, T., Rodhe, H., Scheeren, H. A., Sikka, D., and Williams, J.: Then Indian ocean experiment: widespread air pollution from south and southeast Asia, Science, 291, 1031-1036, 2001.

Lin, C.-I., Baker, M., and Charlson R. J.: Absorption coefficient of atmospheric aerosol: a method for measurement, Appl. Optics, 12, 1356-1363, 1973.

McConnell, J. R., Edwards, R., Kok, G. L., Flanner, M. G., Zender, C. S., Saltzman, E. S., Banta, J. R., Pasteris, D. R., Carter, M. M, Kahl, J. D. W.: 20-th century industrial black carbon emissions altered arctic climate forcing, Science, 317, 1381-1384, 2007.

McDonald, J. D., Zielinska, B., Fujita, E. M., Sagebiel, J. C., Chow, J. C., Watson, J. G.: Fine 30 particle and gaseous emission rates from residential wood combustion, Environ. Sci. Technol., 34, 2080-2091, 2000.

Menon, S., Hansen, J., Nazarenko, J., and Luo, Y.: Climate effects of black carbon aerosols in India and China, Science, 297, 2250-2253, 2002.

\section{AMTD}

4, 1233-1254, 2011

\section{A novel algorithm for retrieving aerosol}

A. Andersson et al.

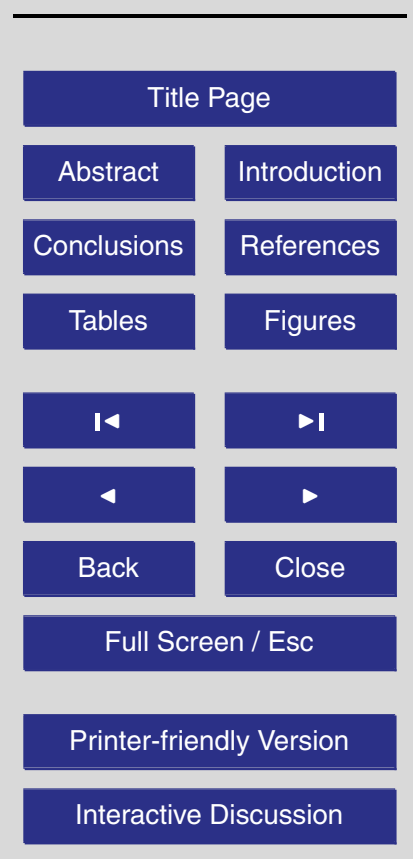


National Institute of Occupational Safety and Health (NIOSH): Elemental Carbon (Diesel Particulate): Method 5040," Issue 3 (Interim), NIOSH Manual of Analytical Methods. 4th ed., DHHS (NIOSH) Publication No. 94-113, edited by: Cassinelli, M. E. and O'Connor, P. F. National Institute for Occupational Safety and Health, US Department of Health and Human Services, Cincinnati, OH.), 1999.

Ram, K. and Sarin, M. M.: Absorption coefficient and site-specific mass absorption efficientcy of elemental carbon over urban, rural and high-altitude sites in India, Environ. Sci. Tech., 43, 8233-8239, 2009.

Ram, K., Sarin, M. M., and Tripathi, S. N.: Inter-comparison of thermal and optical methods for determination of atmospheric black carbon and attenuation coefficient from an urban location in northern India, Atmos. Res., 97, 335-342, 2010.

Ramanathan, V. and Carmichael, G.: Global and regional climate change due to black carbon, Nature Geosci., 1, 221-227, 2008.

Ramanathan, V., Crutzen, P. J., Kiehl, J. T., and Rosenfeld, D.: Aerosols, climate and the 15 hydrological cycle, Science, 294, 2119-2124, 2001

Ramanathan, V., Crutzen, P. J., Lelievald, J., Mitra, A. P., Althausen, D., Anderson, J., Andreae, M. O., Cantrell, W., Cass, G. R., Chung, C. E., Clarke, A. D., Coakley, J. A., Collins, W. D., Conant, W. C., Dulac, F., Heintzenberg, J., Heymsfield, A. J., Holben, B., Howell, S., Hudson, J., Jayaraman, A., Kiehl, J. T., Krishnamurti, T. N., Lubin, D., McFarquhar, G., Novakov, T., Ogren, J. A., Podgorny, I. A., Prather, K., Priestley, K., Prospero, J. M., Quinn, P. K., Rajeev, K., Rasch, P., Rupert, S., Sadourny, R., Satheesh, S. K., Shaw, G. E., Sheridan, P., and Valero, F. P. J.: Indian Ocean Experiment: An integrated analysis of the climate forcing and effects of the great Indo-Asian haze, J. Geophys Res., 106, 28371-28398, 2001.

Schauer, J., Kleeman, M. J., Cass, G. R., and Simoneit, B. R. T.: Measurement of emissions from air pollution sources. $\mathrm{C} 1$ through $\mathrm{C} 30$ organic compounds from medium duty diesel trucks, Environ. Sci. Technol., 33, 1578-1587, 1999

Schmid, O., Artaxo, P., Arnott, W. P., Chand, D., Gatti, L. V., Frank, G. P., Hoffer, A., Schnaiter, M., and Andreae, M. O.: Spectral light absorption by ambient aerosols influenced by biomass burning in the Amazon Basin. I: Comparison and field calibration of absorption measurement techniques, Atmos. Chem. Phys., 6, 3443-3462, doi:10.5194/acp-6-3443-2006, 2006.

Seinfeld J. H. and Pandis, S. N.: Atmospheric chemistry and physics, Wiley, Hoboken, USA, 2006.

Sheesley, R. J., Kruså, M., Krecl, P., Johansson, C., and Gustafsson, Ö.: Source appor-

\section{AMTD}

$4,1233-1254,2011$

\section{A novel algorithm for retrieving aerosol}

A. Andersson et al.

\section{Title Page}

Abstract Introduction

Conclusions References

Tables Figures

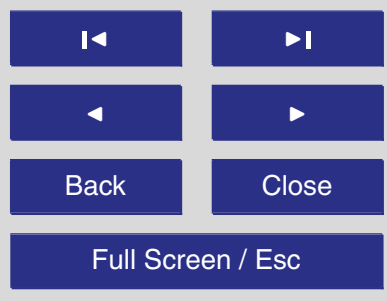

Printer-friendly Version

Interactive Discussion 
tionment of elevated wintertime PAHs by compound-specific radiocarbon analysis, Atmos. Chem. Phys., 9, 3347-3356, doi:10.5194/acp-9-3347-2009, 2009.

Snyder, D. C. and Schauer, J. J.: An inter-comparison of two black carbon instruments and a semi-continuous elemental carbon instrument in the urban environment, Aerosol Sci. Technol., 41, 463-474, 2007.

Weingartner, E., Saathoff, H., Schnaiter, M., Streit, N., Bitnar, B., and Baltensperger, U.: J. Aerosol Sci., 32, 1445-1463, 2003.

\section{AMTD}

$4,1233-1254,2011$

\section{A novel algorithm for} retrieving aerosol

A. Andersson et al.

\section{Title Page}

Abstract

Introduction

Conclusions

References

Tables

Figures

14

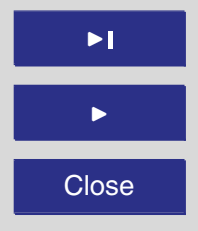

Back

Full Screen / Esc

Printer-friendly Version

Interactive Discussion 


\section{AMTD}

4, 1233-1254, 2011

\section{A novel algorithm for retrieving aerosol}

Table 1. $O C$ and $E C$ concentrations in air, as well as optical parameters derived from the thermo-optical (OCEC) laser transmission at Maldives Climate Observatory at Hanimadhoo $(\mathrm{MCOH})$, Sinhagad (SIN), Aspvreten (ASP) and Stockholm (STO). ATN $\mathrm{RS}_{\mathrm{RS}}$ and $\mathrm{ATN}_{\mathrm{EC}}$ denote the light attenuation coefficients calculated using the method by Ram and Sarin (2009, Eq. (2) and (3)) and the present method (Eq. (2) and (4), respectively. $M A C_{R S}$ and $M A C_{E C}$ denote the analogous mass absorption coefficients. $\mathrm{MCOH}, \mathrm{SIN}$, ASP and STO were measured in triplicates, and the data are presented as mean \pm stdev. $\langle$ STO $>$ is the average of the Stockholm time-series data, where the standard deviation indicate time-variability rather than measurement uncertainties.

\begin{tabular}{lcccccc}
\hline Sample & $\mathrm{OC}\left(\mu \mathrm{g} \mathrm{m}^{3}\right)$ & $\mathrm{EC}\left(\mu \mathrm{g} \mathrm{m}^{3}\right)$ & $\mathrm{ATN}_{\mathrm{RS}}\left(\mu \mathrm{m}^{-1}\right)^{\mathrm{a}}$ & $\mathrm{ATN}_{\mathrm{EC}}\left(\mu \mathrm{m}^{-1}\right)^{\mathrm{a}}$ & $\mathrm{MAC}_{\mathrm{RS}}\left(\mathrm{m}^{2} \mathrm{~g}^{-1}\right)^{\mathrm{a}}$ & $\mathrm{MAC}_{\mathrm{EC}}\left(\mathrm{m}^{2} \mathrm{~g}^{-1}\right)^{\mathrm{a}}$ \\
\hline $\mathrm{MCOH}$ & $0.70 \pm 0.04$ & $0.34 \pm 0.02$ & $4.6 \pm 0.2$ & $2.2 \pm 0.6$ & $13.6 \pm 0.7$ & $6.6 \pm 1.5$ \\
$\mathrm{SIN}$ & $1.95 \pm 0.08$ & $0.400 \pm 0.003$ & $7.3 \pm 0.4$ & $7.0 \pm 0.2$ & $18.2 \pm 0.9$ & $17.4 \pm 0.5$ \\
$\mathrm{ASP}$ & $1.231 \pm 0.008$ & $0.127 \pm 0.001$ & $2.05 \pm 0.05$ & $1.68 \pm 0.07$ & $16.9 \pm 0.6$ & $13.9 \pm 0.7$ \\
STO & $3.56 \pm 0.06$ & $0.48 \pm 0.01$ & $3.2 \pm 0.3$ & $2.6 \pm 0.2$ & $6.7 \pm 0.9$ & $5.5 \pm 0.6$ \\
<STO> & $3.0 \pm 0.4$ & $0.44 \pm 0.09$ & $2.8 \pm 0.8$ & $2.1 \pm 0.5$ & $6.5 \pm 1.8$ & $5.0 \pm 1.7$ \\
\hline
\end{tabular}

${ }^{\text {a }}$ Calculated using a correction factor for multiple scattering effects $C=3.6$.

A. Andersson et al.

\section{Title Page}

\section{Abstract}

Introduction

Conclusions

References

Tables

Figures
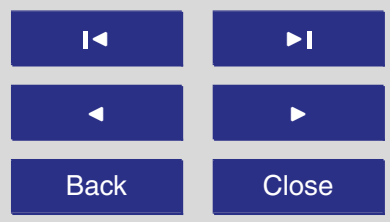

Full Screen / Esc

Printer-friendly Version

Interactive Discussion 
a

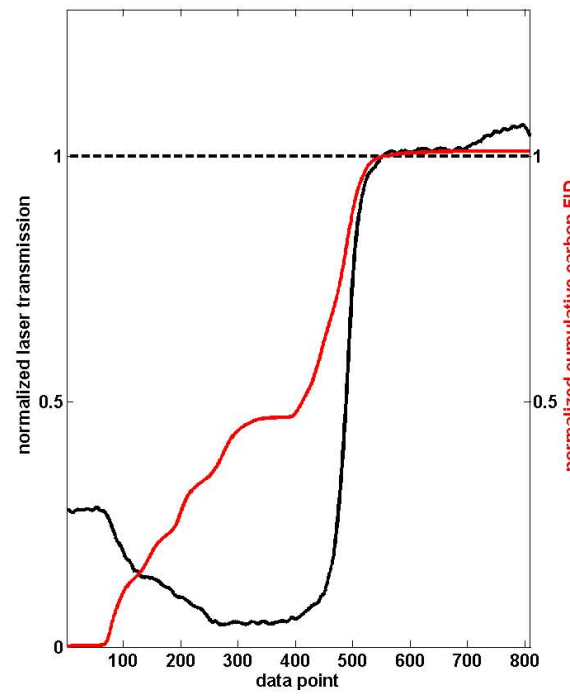

b

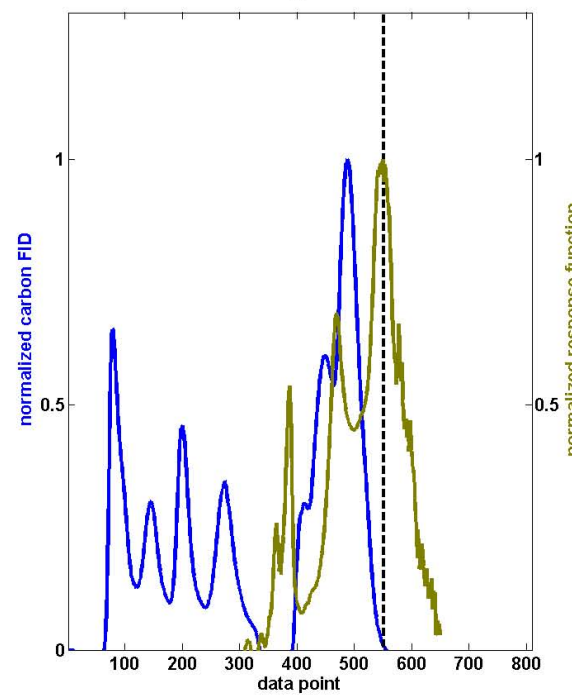

AMTD

4, 1233-1254, 2011

A novel algorithm for retrieving aerosol

A. Andersson et al.

Title Page

Abstract

Introduction

Conclusions

References

Tables

Figures

14

$\rightarrow$

4

Back

Close

Full Screen / Esc

Printer-friendly Version

Interactive Discussion point 750 (out of 810 ) to exclude the internal standard carbon signal. 


\section{AMTD}

4, 1233-1254, 2011
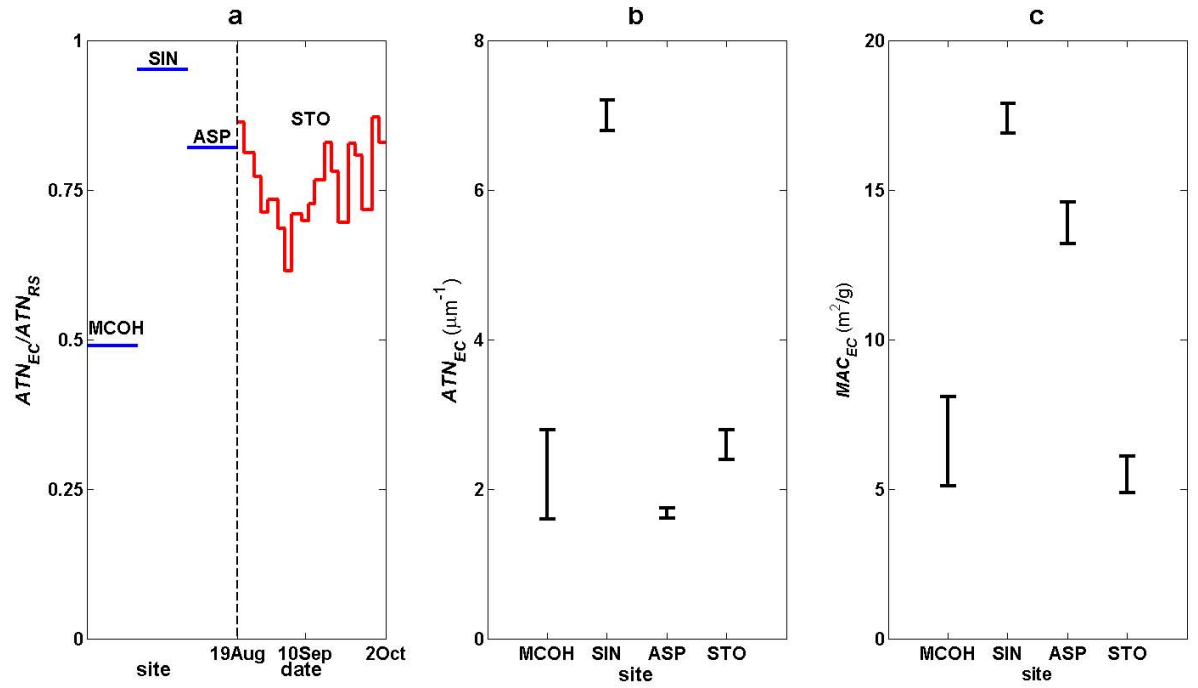

Fig. 2. Optical parameters of EC obtained using the present analysis method of the thermooptical (OC/EC) data. (a) The ratios of light attenuation constants obtained using the present algorithm $\left(\mathrm{ATN}_{\mathrm{EC}}\right)$ and the method described by Ram and Sarin (2009, ATN $\mathrm{RS}$ ) plotted for the different sites: Maldives Climate Observatory at Hanimadhoo (MCOH), Sinhagad (SIN) and Aspvreten (ASP), including time-resolved data for the Stockholm site (STO). In (b) light attenuation data calculated using the present algorithm $\left(\right.$ ATN $\left._{\mathrm{EC}}\right)$ for these four sites are plotted. The error bars indicate triplicate variation. In (c), the corresponding mass absorption crosssections $\left(\mathrm{MAC}_{\mathrm{EC}}\right)$ are plotted.

\section{A novel algorithm for retrieving aerosol}
A. Andersson et al.

\section{Title Page}

\section{Abstract}

Introduction

Conclusions

References

Tables

Figures

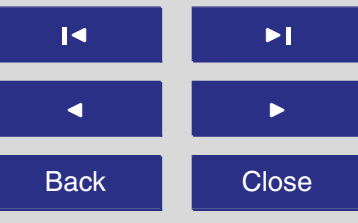

Full Screen / Esc

Printer-friendly Version

Interactive Discussion 


\section{AMTD}

4, 1233-1254, 2011

\section{A novel algorithm for retrieving aerosol}

\section{A. Andersson et al.}

\section{Title Page}

\section{Abstract}

Introduction

Conclusions

References

Tables

Figures
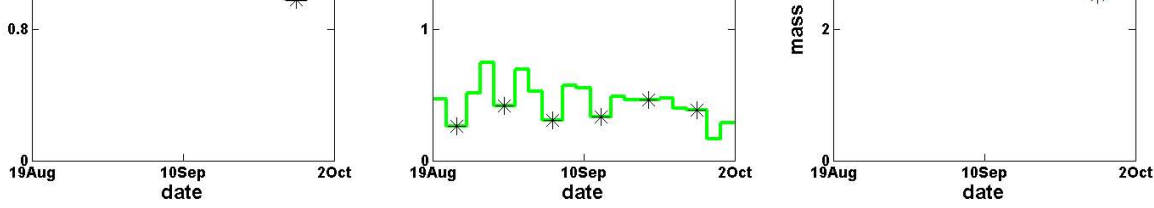

Fig. 3. Times series of thermo-optical (OC/EC) measurements recorded at the Stockholm (STO) site during 19 August-2 October 2008. In (a), the light extinction coefficient, ATN $\mathrm{EC}_{\mathrm{EC}}$, calculated from the OC/EC data is plotted (black). In (b), the concentrations of TC (blue) and EC (green) in ambient air are depicted. In panel (c), the time-dependence of the light absorption cross section, $\mathrm{MAC}_{\mathrm{EC}}$, with respect to $\mathrm{EC}$ (red) are shown. Weekends are marked with *.
14

4

Back

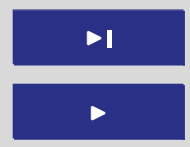

Close

Full Screen / Esc

Printer-friendly Version

Interactive Discussion

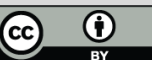

